\title{
Quality of life among caregivers of sickle cell disease patients: a cross sectional study
}

\author{
Badr M. Madani", Rajaa Al Raddadi, Soad Al Jaouni, Mohab Omer and Marie-Isabelle Al Awa
}

\begin{abstract}
Purpose: To assess the quality of life (QoL) of caregivers of children with sickle cell disease $(S C D)$ and to determine the risk factors associated with poor QoL.

Method: A cross sectional study was conducted between 01 and 30 June 2015, in a tertiary care center in western Saudi Arabia to assess various dimensions of QoL by using TNO-AZL Questionnaire for Adult's Health-related Quality of Life (TAAQOL). A total 164 adult caregivers (aged 16 years or more) of children with SCD, who were regularly visiting the department were enrolled (refusal rate $=61.6 \%$ ). The questionnaire scores were transformed into 0-100 scale; with higher scores indicating less difficulty and better QoL Demographic, socioeconomic data and a satisfaction questionnaire regarding participants' lifestyle were collected and analyzed as risk factors for impaired QoL, by comparing different QoL dimensions' scores using independent t-test, Oneway ANOVA, or linear regression, as appropriate.
\end{abstract}

Results: Sixty-three caregivers were included; $79.4 \%$ were mothers, age range $21-71$ years, $64.5 \%$ were from low social class receiving insufficient support and financial needs were unmet for considerable number of families. Analysis of QoL using TAAQOL showed that emotions (median [75th centile] = 44.44 [66.67] for negative and 61.11 [72.22] for positive emotions), sleep quality (66.67 [91.67]) and sexual life (50.00 [83.33]) were the most affected dimensions. Professional achievement (91.67 [100]), cognitive skills (83.33 [100]), and social contact (100 [100]) were relatively preserved. Negative emotions were more marked in mothers and mostly predicted by satisfaction with social relations notably with partner $(B=3.14, p=0.016)$, friends $(B=2.51, p=0.015)$ and relatives $(B=2.69$, $p=0.016)$. Positive emotions were predicted by the levels of satisfaction of the caregiver with his/her health $(B=2.56, p=0.001)$, job achievement $(B=4.54, p=0.001)$, living conditions $(B=2.60, p=0.034)$ and the condition of the diseased child ( $B=2.55, p=0.011)$. A strong correlation was found between sleep quality and cognitive skills.

Conclusion: There are notable financial and emotional burdens on the caregivers of children with SCD affecting various aspects of their QoL, which are likely to be impacted by the individual levels of social and professional achievement. Physicians and health authorities should give particular attention to the QoL of caregivers and families of children with SCD, to help them cope up with the disease and overcome its related psychological and financial impacts.

Keywords: Sickle-cell disease, Caregivers, Parents, Quality of life, Satisfaction; Saudi Arabia

\footnotetext{
* Correspondence: badr.madani@hotmail.com

University of Jeddah, Asfan road, Jeddah 23881, Saudi Arabia
}

(c) The Author(s). 2018 Open Access This article is distributed under the terms of the Creative Commons Attribution 4.0 International License (http://creativecommons.org/licenses/by/4.0/), which permits unrestricted use, distribution, and reproduction in any medium, provided you give appropriate credit to the original author(s) and the source, provide a link to the Creative Commons license, and indicate if changes were made. The Creative Commons Public Domain Dedication waiver (http://creativecommons.org/publicdomain/zero/1.0/) applies to the data made available in this article, unless otherwise stated. 


\section{Background}

World Health Organization estimated that over 5\% of the world population carries genes of hemoglobinopathies. Approximately 23 out of 10,000 people are affected with sickle cell disease (SCD), with the highest prevalence in African countries, 110 out of 10,000 people [1]. However, SCD is also relatively prevalent in some cultures with high rates of consanguinity and large family size, such as in the Middle-East region, including Saudi Arabia, where hemoglobinopathies constitute real public health issues $[2,3]$. SCD is one of the most common genetic disorders in Saudi Arabia, with an overall prevalence rate of 44.1 (42 carriers and 2.1 cases) per 1000 and marked regional variations reaching up to 134.1 per 1000 in the Eastern Region [3, 4].

SCD is a hemoglobinopathy characterized by a chronic anemia with various acute "painful crises" and chronic symptoms that require daily care and sometimes intensive medication; all negatively impacting physical functioning, sleep, school performance, and overall quality of life (QoL) of patients $[5,6]$. An increasing interest to the various aspects of patients' QoL is noted in the recent publications, highlighting the contribution of different factors such as complications, comorbidities, compliance to treatments, etc. [7, 8].

On the other hand, taking care of a child with SCD is a challenging experience for both the caregiver and the other family members $[1,2,9]$. Since, the management of SCD should be family-centered [10], besides the total dependence of the afflicted child on his/her caregiver for general care and treatment, parents, or caregivers, are subjected to continuous pressure; which may, in return, affect the patient's QoL [11]. Consequently, caregivers are developing psychological disorders such as depression and anxiety [2, 11-14]. Several studies have described the association between parenting a child with SCD and psychological distress; approximately 30 to $40 \%$ of caregivers had symptoms of psychological distress [15-17].

Generally, common genetic disorders including SCD, constitute a considerable emotional and financial burden on patients and families, and even on the society, particularly in developing countries [18, 19]. A study from Nigeria, where the disease is highly prevalent, demonstrated that caregivers were exposed to intense pressure with the risk of developing psychological problems; which affected their ability to take care the afflicted children. Caregivers were in crucial need for attention and all kinds of support by both the physicians and authorities [19]. Another Nigerian study exposed a triangular relationship between the patient, the disease and the family. Exclusive caregivers, usually mothers, were the most likely to suffer from psychological problems and physical distress [18].
In developed countries such as Netherlands, female caregivers of children with SCD had significant impairment in the QoL, compared to healthy females and female caregivers of healthy children. All dimensions of the QoL were affected, particularly mood, sleep quality, feeling of happiness, and cognitive functioning [11].

In Saudi Arabia, despite high prevalence of the disease, no comprehensive data about health-related QoL of parents and/or caregivers of patients with SCD has been published so far. Such data will provide an insight that is necessary for optimizing the management of patients with SCD, by opening complementary perspectives to the purely medical follow-up and offering more targeted and specific solutions.

This study was conducted to investigate the QoL of caregivers of children with SCD in Western Saudi Arabia, and to assess the true impact of the illnesses on their overall well-being. Different dimensions of the QoL of caregivers were explored as well as the risk factors associated with deteriorated QoL. The dimensions of QoL that are more affected by the disease and the sub-groups of caregivers who are most exposed to poor QoL outcomes, with regards to the risk factors, were defined. We hypothesized that worse child conditions and lower satisfaction regarding different life domains may be significantly impacting the caregivers' QoL.

\section{Methods}

\section{Population and setting}

A descriptive and analytic cross-sectional study was conducted between 01 June 2015 and 30 June 2015, in King Abdul Aziz University Hospital (KAUH), Jeddah, Kingdom of Saudi Arabia. Parents of the 164 children (aged < 16 years) with SCD following at KAUH were identified using the hospital database and invited to present at the outpatient clinic of KAUH to participate in the study. In addition, adult caregivers of children with SCD visiting the outpatient clinic of KAUH during the study period were directly approached and solicited to respond to the study questionnaire, in case, they had not received the invitation. All eligible and consenting respondents from either method were included. Inclusion criteria were applied as follows: parents, uncles, aunts, brothers or sisters aged 16 years or over, caregivers of a pediatric patient (aged up to 16 years) with a SCD diagnosed $>1$ year ago and registered for treatment in KAUH. There was no restriction on gender, nationality or race to participate in the study. Exclusion criteria were applied as follows: caregivers who did not understand Arabic or English.

\section{Study tool}

Caregivers were interviewed using the TNO-AZL Questionnaire for Adult's Health Related Quality of Life (TAAQOL questionnaire), a validated questionnaire developed by the 
Dutch Institute of Prevention and Health and the Leiden University Hospital (TNO-AZL) [20]. It is a systematic tool to measure health problems or limitations and their impact on general well-being. The questionnaire was translated from Dutch into Arabic, although English version was used for data processing. This questionnaire was chosen because it enables assessing various dimensions of the quality of life that may be separately or mutually impacted. A written permission from the principal author was obtained to use the questionnaire. The questionnaire is divided into 9 subscales, each assessing one of the following dimensions of the QoL: mobility, fine motor skills, cognitive skills, sleep quality, pain, social isolation, job achievement, sexual life, and emotions. Each of these subscales contains 2 to 15 items; each item is answered on a 0 to 3 difficulty scale: $3=$ no difficulty; $2=$ a little; $1=$ some; $0=a$ lot. Item scores are added within each subscale; and raw subscale scores are transformed into $0-100 \%$ scores; with higher scores indicating less difficulty and better QoL. Transformed scores were analyzed as continuous variables.

In addition, participants were investigated regarding the following: 1) demographic and socioeconomic data, 2) characteristics of the care giving (type, frequency), 3) any type of psychological or financial support received, 4) daily free time management, and 5) participants' satisfaction regarding various aspects of life (e.g. health condition, job achievement, relationships, etc.).

\section{Data collection method}

The questionnaire was distributed in the outpatient clinics, emergency department (ER), pediatric wards, and daycare department during the study period week days. A team of residents including the author took on the mission to administer the questionnaire to eligible participants. Given the extent of the interview (30 to $45 \mathrm{~min}$ to complete all questionnaire items), a break was allowed for the participants at any time they suggested.

\section{Ethical clearance}

The study protocol was approved by the ethical committee of the Joint Program of Family and Community Medicine (JPFCM) and by the institutional review board of KAUH.

\section{Statistical methods}

Statistical analysis was carried out using SPSS, version 21 (IBM SPSS Statistics for Windows, Armonk, NY: IBM Corp. 2012). Descriptive statistics were used to present the patterns of participant's answers to the different items of the questionnaire; where continuous data were presented as mean \pm standard deviation and categorical data were presented as frequency (percentages).
Preliminary analysis showed that transformed scores of QoL dimensions showed are not normally distributed, using both Kolmogorov-Smirnov and Shapiro-Wilk tests. Consequently, to analyze risk factors for impaired QoL, correlations with demographic and socioeconomic parameters were analyzed using nonparametric tests including Mann-Whitney U test and Kruskal-Wallis tests, as appropriate. Results were presented as median and range. In case if the risk factors were numerical variables (e.g. age, number of children, lifestyle satisfaction scores), linear regression analysis was used. Linear regression was also carried out to analyze life domains satisfaction scores as predictors for positive and negative emotions. Results are presented as unstandardized regression coefficient (B) with significant level. A $p$-value $<0.05$ was fixed to reject the null hypothesis.

\section{Results}

\section{Demographic and socioeconomic data}

Sixty-three caregivers agreed to participate among 164 regularly visiting the outpatient clinic of KAUH (participation rate $=38.4 \%)$. Of these $50(79.4 \%)$ were mothers and $7(11.1 \%)$ were fathers; mean \pm SD (range) age was $39.5 \pm$ 9.8 (21-71) years. Almost two-third (64.5\%) of the families lived with a monthly income < 1282 USD and only 10 (16.7\%) had registered insurance. Socio-demographic and economic data of the caregivers of children with SCD in Western region of Saudi Arabia is presented in Table 1.

\section{Characteristics of the caregiving}

Analysis of the caregiving patterns showed that 49 (77.8\%) participants were constantly available for the patient as primary caregivers and $45(71.4 \%)$ declared being the exclusive caregivers, while 7 (11.1\%) declared that their partners were the primary caregivers. The family's house was the place of care in 52 (82.5\%) cases; and 39 (63.9\%) reported supporting their children with education and games. The median cost of care expenses was estimated to be 102.5 USD per month per child (range 12.8-384.6 USD). Characteristics of the care giving are presented in Table 2.

\section{Health assessment of caregivers and their partners}

Investigations of medical history showed that $15(26.2 \%)$ caregivers had chronic diseases (14 cases of diabetes, 10 cases of hypertension and 2 cases of SCD). Thirty-five (58.3\%) caregivers took medication regularly. As to partners, 10 (16.1\%) had chronic disease and 31 (58.5\%) took regular medications, according to participants. The median frequency of hospital visits during the last 6 months was 1 visit (range 1-2) in participants and 2 visits (range $1-3)$ in partners, for various complaints. 
Table 1 Socio-demographic and economic data of the caregivers of children with SCD in Western region of Saudi Arabia

\begin{tabular}{lll}
\hline Variables & Frequency & Percentage (\%) \\
\hline Family relationship with the patient & & \\
Father & 7 & 11.1 \\
Mother & 50 & 79.4 \\
Sister & 4 & 6.3 \\
Brother & 2 & 3.2 \\
Marital status & & \\
Single & 6 & 9.5 \\
Married & 55 & 87.3 \\
Widowed & 2 & 3.2
\end{tabular}

Children age category

$\begin{array}{lll}\text { At least one child }<5 \text { years old } & 18 & 28.6 \\ \text { All children aged }>5(5-14) \text { years } & 45 & 71.4\end{array}$

Educational level (participant)

$\begin{array}{lll}\text { Illiterate } & 13 & 20.6 \\ \text { Intermediate or high school } & 32 & 50.8 \\ \text { University of higher } & 18 & 28.6\end{array}$

Educational level (partner)

$\begin{array}{lll}\text { Illiterate } & 5 & 8.9 \\ \text { Intermediate or high school } & 38 & 67.9 \\ \text { University of higher } & 13 & 23.2\end{array}$

Job condition

Employed
Looking for job

Student

Housewife

Free work

Reason of no job

In relation with the patient's

care or health problems

Other reason

Monthly family income (USD) ${ }^{a}$

less than 1330
$1330-2660$
$2660-4000$
more than 4000

Income resources

Salary, company dividends, properties

Family aids (sons)

Social assistance

Social security

None
Insurance company

Table 1 Socio-demographic and economic data of the caregivers of children with SCD in Western region of Saudi Arabia (Continued)

\begin{tabular}{lll}
\hline Variables & Frequency & Percentage (\%) \\
\hline Free treatment & 2 & 3.3 \\
Variables & Mean \pm SD & (min-max) \\
Age of caregivers & $39.5 \pm 9.8$ & $(21-71)$ \\
Number of children per house & $5 \pm 2.0$ & {$[1-12]$}
\end{tabular}

USD United States Dollar, ${ }^{a}$ Income levels are converted from Saudi Riyal (SAR), the local currency, using the conversion rate of $\$ 1=3.75$ SAR

Table 2 Characteristics of caregiving for children with SCD

\begin{tabular}{|c|c|c|}
\hline Variables & Frequency & Percentage (\%) \\
\hline \multicolumn{3}{|l|}{ Primary caregiver } \\
\hline Participant & 49 & 77.8 \\
\hline Partner & 7 & 11.1 \\
\hline Other family member (grandmother, sister) & 2 & 3.2 \\
\hline Alternating care (participant \& partner) & 5 & 7.9 \\
\hline \multicolumn{3}{|l|}{ Place of caregiving } \\
\hline Always home & 52 & 82.5 \\
\hline Home and outside & 9 & 14.3 \\
\hline Outside & 2 & 3.2 \\
\hline \multicolumn{3}{|l|}{ Caregiver's assessment of the level of care } \\
\hline Satisfactory & 36 & 57.2 \\
\hline Acceptable to good & 15 & 23.8 \\
\hline Moderately satisfactory & 8 & 12.7 \\
\hline Unsatisfactory & 4 & 6.3 \\
\hline \multicolumn{3}{|l|}{ Who is the caregiver? } \\
\hline Participant (exclusive) & 45 & 71.4 \\
\hline Participant \& partner & 4 & 6.3 \\
\hline Partner (exclusive) & 11 & 17.5 \\
\hline Other family member (grandmother, sister) & 2 & 3.2 \\
\hline Nurse & 1 & 1.6 \\
\hline \multicolumn{3}{|l|}{ Educational support } \\
\hline Participant & 39 & 63.9 \\
\hline Participant \& partner & 5 & 8.2 \\
\hline Partner & 11 & 18.0 \\
\hline Other family member (grandmother, sister) & 4 & 6.6 \\
\hline Nurse & 2 & 3.3 \\
\hline \multicolumn{3}{|l|}{ Communication with hospital and school } \\
\hline Participant & 35 & 59.3 \\
\hline Participant \& partner & 5 & 8.5 \\
\hline Partner & 17 & 28.8 \\
\hline Other family member (grandmother, sister) & 2 & 3.4 \\
\hline Variable & Median & Quartile \\
\hline Estimated cost of caregiving (SAR) & 400 & $(50-1500)$ \\
\hline
\end{tabular}




\section{Support received and needed by the caregivers}

Most supportive persons were partners, 46 (73.0\%) of the cases, followed by children, 24 (38.1\%), and grandparents, $16(25.4 \%)$ of the cases. Forty one (65.1\%) participants reported having undergone a difficult trial during their life; and 22 (34.9\%) among these stated that they needed support to overcome it; and only $13(20.6 \%)$ received a financial support. The data of support received and needed by caregivers are presented in Table 3.

\section{Daily activities and free time management}

Assessment of daily activities and leisure time showed that $24(38.1 \%)$ of the caregivers reported practicing sport activity, especially walking, with a median $1.5 \mathrm{~h}$ per week (range 0.5-4.2). The other respondents reported using their free time to watch television (33.3\%), read the Quran (14.8\%), or go to the internet (18.5\%). The mean time spent at home for the caregivers was $20.4 \pm 3.3 \mathrm{~h}$ per day and 21 (34.4\%) were concerned about not finding enough time for themselves; although, $27(42.9 \%)$ reported going to restaurant or coffee and 25 (39.7\%) to picnic, on their own time.

Table 3 Support received and needed by caregivers

\begin{tabular}{|c|c|c|}
\hline Variables & Mean \pm SD & (min-max) \\
\hline \multicolumn{3}{|c|}{ Level of psychological support received ${ }^{a}$} \\
\hline From partner (husband or wife) & $1.9 \pm 1.2$ & $(0-3)$ \\
\hline From other relative & $1.6 \pm 1.3$ & $(0-3)$ \\
\hline From friend & $0.9 \pm 1.3$ & $(0-3)$ \\
\hline From neighbor & $0.8 \pm 1.3$ & $(0-3)$ \\
\hline From family doctor & $0.3 \pm 0.8$ & $(0-3)$ \\
\hline \multirow[t]{2}{*}{ From social service } & $0.1 \pm 0.4$ & $(0-3)$ \\
\hline & Frequency & Percentage (\%) \\
\hline \multicolumn{3}{|l|}{ Most supportive persons } \\
\hline Partner (husband/wife) & 46 & 73.0 \\
\hline Children & 24 & 38.1 \\
\hline Grandparents & 16 & 25.4 \\
\hline Sibling & 17 & 27.0 \\
\hline Other family member & 7 & 11.1 \\
\hline Friend & 11 & 17.5 \\
\hline Difficult experience & 41 & 65.1 \\
\hline Support needed & 22 & 34.9 \\
\hline Financial support received & 13 & 20.6 \\
\hline Friend & 9 & 69.2 \\
\hline Charity & 2 & 15.4 \\
\hline Other & 2 & 15.4 \\
\hline
\end{tabular}

a Level of support calculated on a subjective scale: $0=$ absence of support, $1=$ weak, $2=$ moderate and $3=$ strong support

\section{Caregivers' lifestyle satisfaction}

Participants' satisfaction regarding various domains of their lives was assessed on a 0 to 10 subjective scale, where $0=$ not satisfied at all and $10=$ completely satisfied. Results are presented as median scores and are shown in Fig. 1. Reliability testing of this part of the questionnaire on 46 valid observations (excluding the items "job satisfaction" and "education satisfaction" because of their very low response rates) found a Cronbach's Alpha $=0.762$. The most remarkable observations were financial situation, free time activity and life environment being allocated the lowest satisfaction scores (median $=6$ each); while the highest satisfaction scores were observed for relationships with friends and relatives and health condition (median score $=10$, each).

\section{Caregivers' quality of life assessment}

Quality of life assessments using the TAAQOL questionnaire showed a range of mean scores, depending on the given dimension. Reliability testing of this part of the questionnaire on 34 valid observations (excluding the item "fine motor skills" because of the very low response rate) found a Cronbach's Alpha $=0.688$. Results showed that emotions, sleep quality and sexual life were the most affected dimensions in caregivers of children with SCD; with median (75th centile) $=44.44$ (66.67) for negative emotions, 61.11 (72.22) for positive emotions, 66.67 (91.67) for sleep quality and 50.00 (83.33) for sexual life. Assessments of various dimensions of quality of life of caregivers of children with sickle cell disease are presented in Table 4.

\section{Emotional assessments}

Analysis of positive and negative emotions reported during the last month is detailed in Fig. 2. In positive feelings,

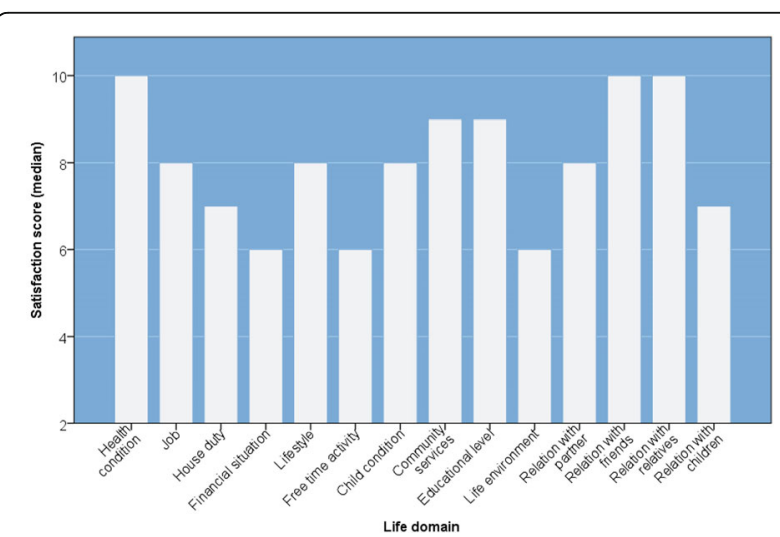

Fig. 1 Life style satisfaction among caregivers of children with sickle-cell disease. Subjective assessment of participants' satisfaction regarding various aspects of their lives: satisfaction levels ranges from 0 (not satisfied at all) to 10 (completely satisfied). Bars represent median satisfaction levels 
Table 4 Assessment of various dimensions of quality of life of caregivers of children with sickle cell disease

\begin{tabular}{|c|c|c|c|c|c|c|}
\hline \multirow[t]{2}{*}{ S. No } & \multirow[t]{2}{*}{ Quality of life dimension } & \multirow[t]{2}{*}{$N$} & & & \multicolumn{2}{|c|}{ Quality of life score $^{a}$} \\
\hline & & & \multicolumn{2}{|l|}{ Range } & Mean & SD \\
\hline 1. & Gross motor aptitudes & 62 & 0 & 100 & 75.13 & 27.14 \\
\hline 2. & Fine motor aptitudes & 10 & 50.00 & 100 & 88.33 & 17.66 \\
\hline 3. & Cognitive skills & 62 & 25.00 & 100 & 79.30 & 22.38 \\
\hline 4. & Sleep quality & 62 & 0 & 100 & 59.54 & 32.98 \\
\hline 5. & Pain & 61 & 0 & 100 & 72.81 & 29.02 \\
\hline 6. & Social contact & 61 & 0 & 100 & 73.36 & 33.36 \\
\hline 7. & Professional achievement & 49 & 0 & 100 & 81.12 & 25.95 \\
\hline 8. & Sexual life & 49 & 0 & 100 & 60.20 & 24.96 \\
\hline 9. & Positive emotions & 59 & 0 & 100 & 59.51 & 20.03 \\
\hline 10. & Negative emotions & 59 & 7.41 & 100 & 48.15 & 22.55 \\
\hline
\end{tabular}

${ }^{a}$ The higher the score the better the QoL in the given subscale; SD Standard deviation

we observed relatively high extent of happiness, cheerfulness and joyfulness; while in negative ones we observed relatively high extent of anxiousness, gloominess and exhaustion. Reliability testing of this part of the TAQOOL questionnaire on 56 valid observations found a Cronbach's Alpha $=0.520$.

\section{Risk factors and predictors for impaired quality of life}

Age of caregiver showed to be a predictor for gross motor aptitudes, where older age was correlated with worse gross motor aptitudes $(\mathrm{B}=-0.94, p=0.006$; Additional file 1: Figure S1); however, age was correlated with any of the other QoL dimensions. Mothers, as caregivers, have worse

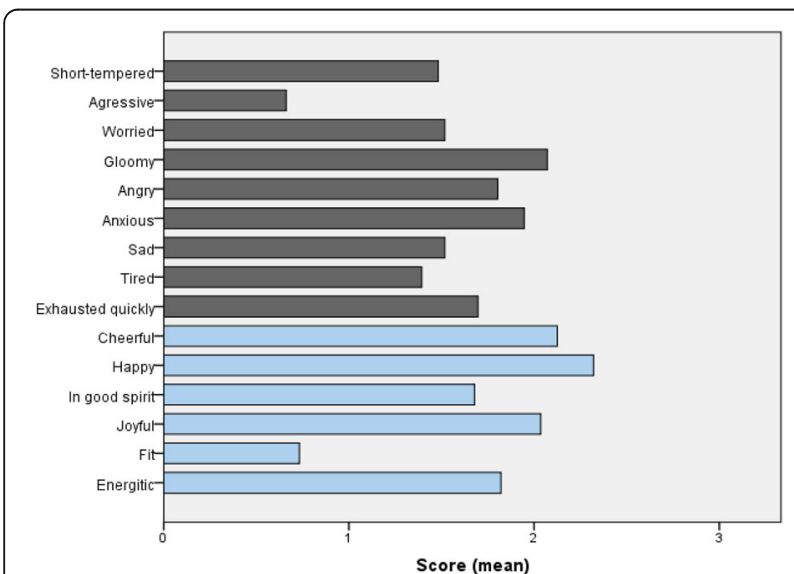

Fig. 2 Past month emotional assessment of caregivers of children with sickle-cell disease. Bars represent the mean score of the given feeling, where high scores indicate high frequency/extent of the feeling during the last month $(0=$ no; $1=$ a little; $2=$ quite; and $3=$ very). Analysis of positive emotions showed high scores of happiness, cheerfulness, and joyfulness; and more than average scores of energetic feeling. Analysis of negative emotions showed relatively high mean scores of gloominess, anxiousness, exhaustion, followed by worry and sadness scores regarding negative emotions (median $=40.74$ ) than fathers (64.91) or siblings (68.52), $p=0.002$ (Kruskal-Wallis test), which was confirmed to be a predictor of bad negative emotion scores in linear regression $(B=16.06, p=0.001)$; however, no significant difference was observed between the three categories of caregivers in the other QoL dimensions. Surprisingly, number of children showed to be a positive factor for both sleep quality $(B=4.05 ; p=0.020$; Additional file 2: Figure $\mathrm{S} 2)$ and positive emotions $(\mathrm{B}=$ 2.36; $p=0.029$; Additional file 3: Figure S3). No remarkable differences in the various QoL dimensions were otherwise found across marital status (married versus single or widowed), educational level (illiterate versus up to high school versus university or higher) or monthly income.

\section{Lifestyle satisfaction as predictor for emotions}

Positive and negative emotions were predicted by various aspects of lifestyle satisfaction using univariate linear regression and stepwise regression for multivariate modeling of predictors that are significant in univariate analysis. In univariate models, positive emotions were predicted by the levels of satisfaction of the caregiver of his/her health, job achievement, living conditions and the condition of the diseased child; while negative emotions were mostly predicted by satisfaction of social relations. Life satisfaction scores as predictors for negative and positive emotions are presented in Table 5. In multivariate model, only satisfaction regarding relations with partner and children remained significant predictors for negative emotions $(\mathrm{B}=3.86 ; p=0.003$ and $\mathrm{B}=-3.65 ; p=0.032$, respectively); while for positive emotions, only satisfaction regarding own health remained a significant predictor $(\mathrm{B}=3.89 ; p=0.025)$.

\section{Discussion}

The findings of this study highlight the impact of difficulties and challenges faced by close family members of children with SCD, who take care of the patients daily. Family-centered care is part of the continuous, effective and comprehensively coordinated standard health care of patients with SCD [21]. The quality of family-centered care in children with special needs is a critical determinant of healthcare services use [22].

The major observations of this study pointed at the relatively difficult demographic and socioeconomic conditions of caregivers, who were mostly housewife mothers (79.4\%) of large families with low financial resources $(64.5 \%)$ and no social assistance or health insurance $(80 \%)$. Comparable profiles were described in African caregivers of children with SCD, where 80 to $89.8 \%$ were mothers with low occupational status, in households living with less than USD 120 per month in $50.7 \%$ of the cases; putting caregivers under huge stress due to inability to cover SCD patient's needs $[12,17,19]$. 
Table $\mathbf{5}$ Life satisfaction scores as predictors for negative and positive emotions

\begin{tabular}{|c|c|c|c|c|c|}
\hline \multirow[t]{2}{*}{ S. No } & \multirow[t]{2}{*}{ Life domain (predictors) } & \multicolumn{2}{|c|}{ Positive emotions } & \multicolumn{2}{|c|}{ Negative emotions } \\
\hline & & $B$ & $p$-value & $B$ & $p$-value \\
\hline 1. & Health condition & 2.56 & $.001^{\mathrm{a}}$ & 2.48 & $.050^{\mathrm{a}}$ \\
\hline 2. & Job (if applicable) & 4.54 & $.001^{\mathrm{a}}$ & 2.56 & .148 \\
\hline 3. & House duty (if housewife) & 2.60 & $.034^{\mathrm{a}}$ & -0.19 & .882 \\
\hline 4. & Financial situation & 1.75 & .075 & 1.22 & .274 \\
\hline 5. & Life style & 2.54 & $.025^{\mathrm{a}}$ & 2.07 & .110 \\
\hline 6. & Free time activity & 1.10 & .250 & 0.75 & .480 \\
\hline 7. & Child condition and quality of care & 2.55 & $.011^{\mathrm{a}}$ & 1.00 & .365 \\
\hline 8. & Local services (around home) & -0.06 & .947 & 0.54 & .577 \\
\hline 9. & Education (if student) & 2.39 & $.045^{\mathrm{a}}$ & 1.83 & .229 \\
\hline 10. & Life environment & 1.95 & $.039^{\mathrm{a}}$ & 1.26 & .237 \\
\hline 11. & Relation with partner & 2.21 & .056 & 3.14 & $.016^{\mathrm{a}}$ \\
\hline 12. & Relation with friends & 0.38 & .660 & 2.51 & $.015^{\mathrm{a}}$ \\
\hline 13. & Relation with relatives & 0.87 & .376 & 2.69 & $.016^{\mathrm{a}}$ \\
\hline 14. & Relation with children & 0.17 & .912 & -3.10 & .079 \\
\hline
\end{tabular}

${ }^{a}$ Statistically significant ( $p$-value $\leq 0.05$ ); $B$ Unstandardized regression coefficient

Financially, the estimated cost of caregiving (400 SAR = USD 107 in average) was relatively high compared with the socioeconomic conditions of the participants' families attributing the lowest satisfaction score for financial situation, out of 13 other life domains. Studies from Nigeria, where SCD is highly prevalent, reported an average USD 333 of monthly health expenditure in households with a child afflicted with SCD; which represented up to $34.4 \%$ of the family income and significantly impacted finances of $58.2 \%$ of the families [9, 23]. Financial stress was described as a significant factor for caregivers difficulty coping with their afflicted children; and the psychosocial impact of the financial burden was more remarkable during SCD crises [2, 23].

On the other hand, most of the tasks and responsibilities related to the caregiving were home-centered and undertaken by the exclusive caregivers. The activities included helping patients to take medications, assisting them during recurrent disease complications and intermittent crises, carrying them to the clinics and hospitals for recurrent blood transfusions or periodic visits, as well as communicating with hospital and school. Consequently, more than half of the interviewees declared lack of time for to take of themselves, exhibiting low participation rates in various daily activities. Similar results were reported in Netherlands, where data indicated a limitation in daily activities of caregivers in relation with the extensive care schedule; including hospital visits, emergency crises and other duties related to SCD child condition [11]. If the importance of the caregiver's role seems apparent in case of young patients, it was demonstrated to be a significant factor for improving adherence to care even for adolescent patients, who have greater level of autonomy and involvement in their own care [24]. Paradoxically, although being challenging for caregivers, frequent hospital visits for regular blood transfusion therapy are associated with a better QoL of the diseased child. All these factors constitute a permanent pressure on caregivers, which may affect their mental and physical wellbeing, compromising their quality of life and negatively affecting their behaviors and selfrespect [19].

Majority of the interviewees (80.9\%) declared being fairly or highly satisfied of the level of care provided within the family to their afflicted child. In a society like Saudi Arabia, which is characterized by strong family and spiritual values, home and family-centered care may be a determinant of success in the continuous care of patients with special needs. This is demonstrated by psychological (and financial) support received by caregivers mostly coming from their natural social environment; especially from partners, other family members, friends, and neighbors. Further, life domain satisfaction questionnaire revealed that caregivers are best satisfied of their relations with their children, other relatives' partners and friends. The relationship between parents and their other, non-diseased, children (siblings of the diseased child) could be dominated by a shift in attention toward the diseased child, a protective attitude regarding the siblings from the pain of their brother/sister, and or their initiation to his/her care; and siblings may develop supportive and responsible attitude in that regard [25]. 
Assessment of the QoL showed that caregivers of children with SCD have impaired sleep quality and unsatisfactory emotional and sexual life but relatively conserved social and professional achievements. In addition, emotional assessments showed high incidence of anxiousness and feeling of exhaustion and negative trends regarding fitness and energetic feeling; although, a positive trend was observed regarding both happiness and joyfulness feelings. Comparable data were found in two Nigerian studies, where authors reported high proportion of feeling of unhappiness, expressed depressive symptoms, and $2 \%$ of suicidal ideations in caregivers. A close monitoring was then recommended with anti-depressive medication $[17,19]$. A French study conducted in 2007 evaluated the incidence of post-traumatic stress disorder in 11 children with SCD and their parents following painful crises episodes. The study demonstrated the presence of post-traumatic stress disorders (PTSD) in both afflicted children and their parents. The authors recommended to conduct few more similar studies to address the relation between SCD painful crises and PTSD [15]. In Netherlands, a higher incidence of depressive moods and feeling of unhappiness was found among caregivers which was associated to marked guilt feeling and fear from having another sick child [11]. Furthermore, the same study reported decreased motor and cognitive functioning in caregivers, which was attributed to the lack of sleep resulting from the frequently continuous caregiving, associated sometimes to interrupted sleep pattern, a lack of vigor and vitality [11]. These data are consistent with our findings showing a positive correlation between sleep quality and cognitive skills supposing significant impact of bad sleep quality on cognitive functioning. On the other hand, sleep quality of the caregivers significantly improved in families with more number of children; which was also significantly correlated with more positive emotions among caregivers. These observations further support the effective role siblings can play in taking care of their diseased brother/sister; and suggest that sharing the caregiving with the other family members may be a crucial factor to preserve the QoL of the caregivers, in the long term.

The primary limitation of our study was difficult to reach all patients' caregivers, due to unavailability of contact details in the patients' files, in addition to the relatively short timeframe of the study; which resulted in the low participation rate and small sample size. Other aspects limiting generalization of the results include the single-center design, convenience sampling, and nonvalidation of the Arabic version of the tool. Further, approaching the QoL dimensions with interview-based survey may increase subjectivity in responses and expose to social desirability bias.

\section{Conclusion}

This study was an extension to the previous studies that highlighted the impact of chronic diseases on the families \& caregivers of SCD children. The findings of this study demonstrated the huge financial and emotional burdens on the caregivers, who are in need of significant attention and focus in solving their psychosocial difficulties, in order to allow them to give more attention to their sick children and help them to cope up with their illness. The rich social and cultural features of the Saudi society constitute helpful resources for the caregivers of children with SCD, with potentially effective financial and psychological support; however, this should not downplay the role of public institutions and authorities in providing these families with the helping facilities and the required support.

Physicians and healthcare providers should be aware of the huge burdens on caregivers and orient them towards appropriate solutions, to help them meet their needs and improve their QoL and that of their diseased children.

The creation of organizations, groups and networks should be encouraged to support the SCD patients and their families, offering them an environment of free exchange and expression about their daily problems and sufferings and providing them with the useful advice and eventual financial support. Further studies are warranted in Saudi Arabia to investigate the psychosocial burden of SCD on the caregivers.

\section{Additional files}

Additional file 1: Figure S1. Linear correlation of gross motor aptitude with age. (DOCX $76 \mathrm{~kb}$ )

Additional file 2: Figure S2. Linear correlation of sleep quality with the number of children. (DOCX $76 \mathrm{~kb}$ )

Additional file 3: Figure S3. Linear correlation of positive emotions with the number of children. (DOCX $76 \mathrm{~kb}$ )

\section{Abbreviations}

KAUH: King Abdul Aziz University Hospital; PTSD: Post-traumatic stress disorder; QoL: Quality of life; SAR: Saudi Riyals; SCD: Sickle cell disease; TAAQOL: TNO-AZL Questionnaire for Adult's health-related Quality of Life

\section{Acknowledgments}

The author would like to acknowledge Prof. Martha Grootenhuis for providing me with the questionnaire, the author would also like to acknowledge the following names: Eman Al Beladi, Khuld Saeedi, Layan Arafah, Mada Sultan, Rana Saad, Lubnah Al Qurashi, Duaa Jasteniah, Haneen, for their valuable contribution in data collection.

Availability of data and materials

The datasets used and/or analyzed during the current study are available from the corresponding author on reasonable request.

Authors' contributions

BM carried out the writing and the overall designing of the thesis, data collection and processing, RA assisted the corresponding author regarding methodology writing and statistics, SA assisted the corresponding author 
regarding clinical background writing and patients database access, $\mathrm{MO}$ and MA both carried out the translation of the original questionnaire, discussion writing, manuscript drafting and also contributed in data collection. All authors read and approved the final manuscript.

\section{Ethics approval and consent to participate}

All procedures performed in studies involving human participants were in accordance with the ethical standards of the institutional and/or national research committee and with the 1964 Helsinki declaration and its later amendments or comparable ethical standards.

Informed consent was obtained from all individual participants included in the study.

\section{Consent for publication}

Not applicable.

\section{Competing interests}

The authors declare that they have no competing interests.

\section{Publisher's Note}

Springer Nature remains neutral with regard to jurisdictional claims in published maps and institutional affiliations.

Received: 25 January 2018 Accepted: 3 September 2018

Published online: 10 September 2018

\section{References}

1. Modell B, Darlison M. Global epidemiology of haemoglobin disorders and derived service indicators. Bull World Health Organ SciELO Public Health. 2008;86(6):480-7.

2. Ohaeri JU. Shokunbi WA. Psychosocial burden of sickle cell disease on caregivers in a Nigerian setting. J Natl Med Assoc National Medical Association. 2002;94(12):1058

3. El-Hazmi MAF, Al-Hazmi AM, Warsy AS. Others. Sickle cell disease in Middle East Arab countries. Indian. J Med Res Medknow Publications. 2011;134(5):597.

4. Memish ZA, Owaidah TM, Saeedi MY. Marked regional variations in the prevalence of sickle cell disease and $\$ \beta \$$-thalassemia in Saudi Arabia: findings from the premarital screening and genetic counseling program. J Epidemiol Glob Health Elsevier. 2011;1(1):61-8.

5. Dampier C, Lieff S, LeBeau P, Rhee S, McMurray M, Rogers Z, et al. Healthrelated quality of life in children with sickle cell disease: a report from the comprehensive sickle cell centers clinical trial consortium. Pediatr Blood Cancer [Internet]. 2010;55(3):485-94. Available from: http://doi.wiley.com/10. 1002/pbc.22497

6. Piel FB. The present and future global burden of the inherited disorders of hemoglobin. Hematol Oncol Clin North Am [Internet]. 2016;30(2):327-41. Available from: http://linkinghub.elsevier.com/retrieve

7. Badawy SM, Thompson AA, Lai J-S, Penedo FJ, Rychlik K, Liem RI. Healthrelated quality of life and adherence to hydroxyurea in adolescents and young adults with sickle cell disease. Pediatr Blood Cancer [Internet]. 2017; 64(6):e26369. Available from: http://doi.wiley.com/10.1002/pbc.26369

8. Panepinto JA, Bonner M. Health-related quality of life in sickle cell disease: past, present, and future. Pediatr Blood Cancer [Internet]. 2012;59(2):377-85. Available from: http://doi.wiley.com/10.1002/pbc.24176

9. Olatunya OS, Ogundare EO, Fadare JO, Oluwayemi IO, Agaja OT, Adeyefa BS, et al. The financial burden of sickle cell disease on households in Ekiti, Southwest Nigeria. Clin Outcomes Res CEOR. Dove Press. 2015;7:545.

10. Kell RS, Kliewer W, Erickson MT, Ohene-Frempong K. Psychological adjustment of adolescents with sickle cell disease: relations with demographic, medical, and family competence variables. J Pediatr Psychol Soc Ped Psychology. 1998;23(5):301-12.

11. van den Tweel XW, Hatzmann J, Ensink E, van der Lee JH, Peters M, Fijnvandraat $\mathrm{K}$, et al. Quality of life of female caregivers of children with sickle cell disease: a survey. Haematologica. Haematologica. 2008;93(4):588-93.

12. Wonkam A, Mba CZ, Mbanya D, Ngogang J, Ramesar R, Angwafo FF III. Psychosocial burden of sickle cell disease on parents with an affected child in Cameroon. J Genet Couns Springer. 2014;23(2):192-201.

13. Thompson RJ, Gil KM, Burbach DJ, Keith BR, Kinney TR. Role of child and maternal processes in the psychological adjustment of children with sickle cell disease. J Consult Clin Psychol American Psychological Association. 1993;61(3):468
14. Moskowitz JT, Butensky E, Harmatz P, Vichinsky E, Heyman MB, Acree M, et al. Caregiving time in sickle cell disease: psychological effects in maternal caregivers. Pediatr Blood Cancer. Wiley Online Library. 2007;48(1):64-71.

15. Hofmann $M$, de Montalembert $M$, Beauquier-Maccotta $B$, de Villartay $P$, Golse B. Posttraumatic stress disorder in children affected by sickle-cell disease and their parents. Am J Hematol. [New York, AR Liss]. 2007; 82(2):171-2.

16. Brown RT, Lambert R, Devine D, Baldwin K, Casey R, Doepke K, et al. Riskresistance adaptation model for caregivers and their children with sickle cell syndromes. Ann Behav Med Springer. 2000;22(2):158-69.

17. Tunde-Ayinmode MF. Psychosocial impact of sicke cell disease on moethers of affected children seen at University of Ilorin Teaching Hospital, Ilorin, Nigeria. East Afr med J Kenya Medical Association. 2007;84(9):410-9.

18. Tunde-Ayinmode MF. Children with sickle cell disease who are experiencing psychosocial problems concurrently with their mothers: a Nigerian study. Afr J Psychiatry In House Publications. 2011;14(5):392-401.

19. Adegoke SA, Kuteyi EA. Psychosocial burden of sickle cell disease on the family, Nigeria. African J Prim Heal care Fam Med AOSIS OpenJournals. 2012;4(1). https://doi.org/10.4102/phcfm.v4i1.380.

20. Bruil J, Fekkes $M$, Vogels $T$, Verrips $E$. The validity and reliability of the TAAQOL: a health-related quality of life instrument comprising health status weighted by the impact of problems on well being. Qual Life Res JSTOR. $2001 ; 257$.

21. Rattler TL, Walder AM, Feng H, Raphael JL. Care coordination for children with sickle cell disease: A Longitudinal Study of Parent Perspectives and Acute Care Utilization. Am J Prev Med Elsevier. 2016:51(1):S55-61.

22. Raphael JL, Mei M, Brousseau DC, Giordano TP. Associations between quality of primary care and health care use among children with special health care needs. Arch Pediatr Adolesc Med. American Medical Association 2011;165(5):399-404

23. Brown BJ, Okereke JO, Lagunju IA, Orimadegun AE, Ohaeri JU, Akinyinka OO. Burden of health-care of carers of children with sickle cell disease in Nigeria. Health Soc care community. Wiley Online Library. 2010;18(3):289-95.

24. Crosby LE, Modi AC, Lemanek KL, Guilfoyle SM, Kalinyak KA, Mitchell MJ. Perceived barriers to clinic appointments for adolescents with sickle cell disease. J Pediatr Hematol Oncol NIH Public Access. 2009;31(8):571.

25. Graff JC, Hankins JS, Hardy BT, Hall HR, Roberts RJ, Neely-Barnes SL. Exploring parent-sibling communication in families of children with sickle cell disease. Issues Compr Pediatr Nurs Taylor \& Francis. 2010;33(2):101-23.

\section{Ready to submit your research? Choose BMC and benefit from:}

- fast, convenient online submission

- thorough peer review by experienced researchers in your field

- rapid publication on acceptance

- support for research data, including large and complex data types

- gold Open Access which fosters wider collaboration and increased citations

- maximum visibility for your research: over $100 \mathrm{M}$ website views per year

At BMC, research is always in progress.

Learn more biomedcentral.com/submissions 